\title{
PENGARUH LIKUIDITAS, CAPITAL INTENSITY TERHADAP AGRESIVITAS PAJAK \\ ( Studi empiris perusahanManufaktur sub sektor industri dasar dan kimia \\ yang terdaftar di BEI tahun 2012-2016.)
}

\author{
DONNY INDRADI \\ Prodi Akuntansi S1 Universitas Pamulang \\ donny03.unpam@gmail.com
}

\begin{abstract}
The purpose of this research is to know and analyze the influence of liquidity, capital intensity against tax aggressiveness. This study uses secondary data used in this research is taken from the annual financial statements of manufacturing companies (annual report) listed on the Stock Exchange during the period 20122016 which can be seen on the official website that is www.idx.co.id, journals or articles related to the purpose of research .. Data processing using Statistical Product and Service Solution for Windows version 22 (SPSS version 22) and microsoft excell. Research Method using quantitative method with purposive sampling method. The analysis method used is Classic Assumption Test (Normality Test, Multicolinearity Test, Heterosedaktisitas Test and autocorrelation test), Multiple Linear Regression Test, Correlation Coefficient Test, Determination Coefficient Test, F Test and Test t. Research population population of 44 companies in 5 years and sampling used as many as 70 data. Based on the results of multiple linear regression test, partial test ( $\mathrm{t}$ test) and simultaneous test (f test), Liquidity effect on tax aggressiveness, Capital intensity has no effect on tax aggressiveness. While simultaneously Liquidity and Capital Intensity have an effect on Aggressiveness of Tax
\end{abstract}

Keywords: Liquidity, Capital Intensity and Aggressiveness of Tax

\begin{abstract}
Abstrak
Tujuan dari penelitian ini adalah untuk mengetahui dan menganalisis pengaruh likuiditas, capital intensity terhadap agresifitas pajak. Penelitian ini menggunakan data Data sekunder yang digunakan dalam penelitian ini di ambil dari laporan keuangan tahunan perusahaan manufaktur (annual report) yang terdaftar di BEI selama periode 2012-2016 yang dapat ilihat di situs resminya yaitu www.idx.co.id, dan jurnal-jurnal atau artikel yang berhubungan dengan tujuan penelitian.. Pengolahan data menggunakan Statistical Product and Service Solution untuk Windows versi 22 (SPSS versi 22) dan microsoft excell. Metode Penelitian menggunakan metode kuantitatif dengan metode purposive sampling. Metode analisis yang digunakan adalah Uji Asumsi Klasik (Uji Normalitas, Uji
\end{abstract}


Multikolinearitas, Uji Heterosedaktisitas dan uji autokorelasi), Uji Regresi Linier Berganda, Uji Koefisien Korelasi, Uji Koefisien Determinasi, Uji F dan Uji t. Populasi objek penelitian sebanyak 44 Perusahaan dalam 5 tahun dan samplingyang digunakan sebanyak 70 data. Berdasarkan hasil uji regresi linier berganda, uji secara parsial (uji t) dan uji secara bersamaan (uji f), Likuiditas berpengaruh terhadap Agresivitas pajak, Capital intensity tidak berpengaruh terhadap agresivitas pajak. Sedangkan secara bersamaan Likuiditas dan Capital Intensity berpengaruh terhadap Agresivitas Pajak

Kata Kunci : Likuiditas, Capital Intensity dan Agresivitas Pajak

\section{PENDAHULUAN}

Seiring meningkatnya pertumbuhan ekonomi di Indonesia maka pendapatan penduduk akan meningkat. Semakin banyak perusahaan yang didirikan baik dalam skala usaha kecil maupun besar. Persaingan yang lebih kompetitif terlihat dalam perusahaan dengan skala usaha besar, yaitu perusahaan yang terdaftar dalam Bursa Efek Indonesia (perusahaan go publik). Perusahaan go publik memiliki kewajiban untuk menyampaikan laporan keuangan setiap tahun. Laporan keuangan tersebut merupakan bentuk pertanggungjawaban kepadapara pemangku kepentingan, antara lain pemegang saham, karyawan, pemasok, kreditur, regulator, pelanggan, lingkungan, dan masyarakat luas.

Pajak yang diasumsikan sebagai biaya atau beban sangat mempengaruhi pihak manajemen perusahaan dalam meningkatkan laba (profit). Secara ekonomis pajak merupakan unsur pengurangan laba yang tersedia bagi perusahaan untuk dibagi sebagai deviden maupun diinvestasikan kembali. Usaha memaksimumkan laba dilakukan perusahaan dengan melakukan efisiensi segala macam biaya termasuk biaya pajak. Misalnya, pembayaran sanksi pajak yang tidak seharusnya terjadi merupakan pemborosan sumber daya perusahaan. Penghindaran pemborosan tersebut merupakan aptimalisasi alokasi sumber daya perusahaan yang lebih produktif dan efisiensi sehingga minimalisasi pemborosan sumber daya tersebut dapat memaksimalkan kinerja dengan benar. Pajak yang diperoleh dari wajib pajak pribadi maupun wajib pajak badan digunakan pemerintah sebagai pengumpul pajak untuk melaksanakan tanggung jawab negara di berbagai sektor kehidupan untuk mencapai kesejahteraan rakyat dan bangsa Indonesia. Wajib pajak yang taat dalam membayar pajak telah turut serta membantu pemerintah dan negara dalam usaha peningkatan kesejahteraan rakyat dan bangsa Indonesia, serta turut dalam usaha pembangunan negara Indonesia secara umum. Oleh karena itu penting bagi pemerintah untuk mengetahui faktor-faktor yang dapat mempengaruhi besarnya penerimaan pajak sehingga dapat menyusun kebijakan yang tepat dan sesuai dengan ketentuan perpajakan.

Upaya pemerintah untuk melakukan pengoptimalan dalm sektor pajak ini bukan tanpa kendala. Salah satu kendala pemeritah dalam upaya pengoptimalan sektor pajak ini adalah penghindaran pajak (Tax Avoidance) dan penggelapan 
pajak ( Tax Evasion) atau dengan berbgai macam kebijakan yang diterapkan perusahaan untuk meminimalkan jumlah pajak yang dibayar perusahaan Pembayaran pajak yang sesuai dengan ketentuan tentunya akan bertentangan dengan tujuan utama perusahaan, yaitu memaksimalkan keuntungan atau laba, sehingga perusahaan berusaha untuk meminimalkan biaya pajak yang ditanggungnya. Cara yang dilakukan oleh perusahaan antara lain dengan tax planning atau dengan agresivitas pajak.

Dalam bidang akuntansi, pajak merupakan salah satu komponen biaya yang dapat mengurangi laba perusahaan. Besarnya pajak yang harus disetorkan ke kas negara tergantung dari besarnya jumlah laba yang didapat perusahaan selama satu tahun. Pembayaran pajak yang sesuai dengan ketentuan tentunya akan bertentangan dengan tujuan utama perusahaan, yaitu memaksimalkan keuntungan atau laba, sehingga perusahaan berusaha untuk meminimalkan biaya pajak yang ditanggungnya (Ardyansyah, 2014). Cara yang dilakukan oleh perusahaan antara lain dengan tax planning atau dengan agresivitas pajak.

Tindakan agresif pajak adalah suatu tindakan yang ditujukan untuk menurunkan laba kena pajak melalui perencanaan pajak baik menggunakan cara yang tergolong atau tidak tergolong tax evasion (Sari dan Martani. 2010). Lanis dan Richardson (2012) menjelaskan bahwa pajak merupakan salah satu hal penting dalam pengambilan keputusan. Keputusan manajerial yang menginginkan meminimalkan biaya pajak perusahaan dilakukan melalui tindakan agresif pajak yang semakin marak dilakukan oleh perusahaan-perusahaan di dunia. Namun demikian, tindakan agresif pajak dapat menghasilkan biaya dan manfaat yang signifikan bagi perusahaan.

Pajak merupakan salah satu bagian dari kewajiban jangka pendek perusahaan. Kemampuan perusahaan untuk melaksanakan kewajiban jangka pendeknya dapat dilihat dari rasio likuiditas. Apabila perusahaan memiliki rasio likuiditas yang tinggi maka perusahan tersebut sedang berada dalam kondisi arus kas yang lancar. Kewajiban jangka pendek akan mampu dipenuhi apabila rasio likuiditas perusahaan sedang dalam keadaan yang tinggi (Suyanto dan Supramono, 2012). Apabila perusahaan sedang berada dalam kondisi keuangan yang baik, pemerintah berharap agar perusahaan tersebut melunasi atau melaksanakan kewajiban pajaknya tepat waktu (Suyanto dan Supramono, 2012).

Capital intensity atau rasio intensitas modal adalah aktivitas investasi perusahaan yang dikaitkan dengan investasi aset tetap dan persediaan. Rasio intensitas modal dapat menunjukkan efisiensi penggunaan aktiva untuk menghasilkan penjualan. Capital intensity juga dapat didefinisikan dengan bagaimana perusahaan berkorban mengeluarkan dana untuk aktivitas operasi dan pendanaan aktiva guna memperoleh keuntungan perusahaan.

Penelitian tentang agresivitas pajak telah banyak diteliti oleh berbagai pihak dengan variabel yang berbeda dan memiliki bukti empiris yang berbeda pula. Sebagai contoh, penelitian yang dilakukan oleh Suyanto dan Supramono (2012) menemukan likuiditas, tarif pajak dan komposisi saham tidak berpengaruh signifikan terhadap agresivitas pajak perusahaan. Leverage berpengaruh signifikan terhadap agresivitas pajak perusahaan, komisaris independen 
berpengaruh signifikan terhadap agresivitas pajak perusahaan, manajemen laba berpengaruh signifikan terhadap agresivitas pajak perusahaan.

Penelitian Adisamartha dan Noviari (2015) menemukan likuiditas dan intensitas persediaan berpengaruh positif dan signifikan pada tingkat agresivitas pajak. Sementara faktor leverage dan intensitas aset tetap tidak berpengaruh signifikan pada tingkat agresivitas wajib pajak badan. Penelitian Kurniasih, Sari (2013) menunjukkan ROA, leverage, corporate governance, ukuran perusahaan dan kompensasi rugi fiskal berpengaruh secara simultan terhadap tax avoidance.

Penelitian Fikriyah (2013) menunjukkan bahwa likuiditas, leverage, profitabilitas tidak berpengaruh signifikan sedangkan karakteristik kepemilikan berpengaruh signifikan. Penelitian Sutatik, dkk. (2015) menunjukkan bahwa ukuran perusahaan, leverage, capital intensity, inventory intensity, cost of debit berpengaruh signifikan. Penelitian Ardyansyah pada tahun 2014 menunjukkan bahwa size dan komisaris independen berpengaruh signifikan terhadap ETR.Sedangkan leverage, profitability dan capital intensity ratio tidak berpengaruh signifikan terhadap ETR.

Penelitian ini dilakukan untuk mencari informasi terkait dengan ketaatan perusahaan dalam membayar pajak atau perusahaan melakukan tindakan agresivitas pajak. Penelitian ini mengggunakan proksi effective tax rate (ETR) sebagai pengukuran agresivitas pajak perusahaan. ETR dianggap mampu merefleksikan perbedaan antara perhitungan laba buku dengan laba fiskal (Putri, 2013).

Berdasarkan latar belakang dan penelitian sebelumnya maka penulis tertarik untuk meneliti:

"Pengaruh Likuiditas, Capital Intensity Terhadap Agresifitas Pajak". Studi empiris perusahan Manufaktur sub sektor industri dasar dan kimia yang terdaftar di BEI tahun 2012-2016.

\subsection{Perumusan Masalah}

Berdasarkan latar belakang di atas, peneliti merumuskan pertanyaan penelitian sebagai berikut :

1. Apakah likuiditas (LIQ) berpengaruh terhadap agresivitas pajak (ETR)?

2. Apakah Capital intensity (CAPIN) berpengaruh terhadap agresivitas pajak (ETR)?

3. Apakah Likuiditas (LIQ), dan Capital intensity (CAPIN) berpengaruh terhadap agresivitas pajak (ETR)?

\subsection{Tujuan Penelitian}

Berdasarkan perumusan masalah di atas, tujuan penelitian ini adalah:

1. Menganalisis pengaruh likuiditas terhadap agresivitas pajak

2. Menganalisis pengaruh capital intensity terhadap agresivitas pajak.

3. Menganalisis pengaruh likuiditas, dan capital intensity terhadap agresivitas pajak. 


\section{LANDASAN TEORI}

\subsection{Teori Keagenan (Agency Theory)}

Teori agensi menjelaskan mengenai adanya hubungan antara pihak pemberi kewenangan (principal) dengan pihak yang diberi kewenangan (agent) (Nugraha, 2015). Luayyi (2010) dalam Ardyansah (2014) menyebutkan bahwa dalam teori agensi atau keagenan terdapat kontrak atau kesepakatan antara pemilik sumber daya dengan manajer untuk mengelola perusahaan dan mencapai tujuan utama perusahaan yaitu memaksimalkan laba yang akan diperoleh, sehingga memungkinkan manajer melakukan berbagai cara untuk mencapai tujuan tersebut baik cara yang baik ataupun cara yang merugikan banyak pihak.

Teori agensi muncul ketika ada sebuah perjanJIAn hubungan kerja antara principle yang memiliki wewenang dengan agent atau pihak yang diberi kewenangan untuk menjalankan perusahaan (Nugraha, 2015). Manajer (agent) memiliki kewajiban untuk memberikan informasi mengenai perusahaan kepada pemilik perusahaan (principle) karena manajer dianggap lebih memahami dan mengetahui keadaan perusahaan yang sebenarnya (Ardyansyah, 2014).

Namun terkadang manajer tidak melaporkan keadaan perusahaan seperti apa yang sebenarnya. Hal ini bisa saja dilakukan untuk menguntungkan manajer dan menutupi kelemahan kinerja manajer. Tindakan manajer yang seperti ini biasanya dilakukan karena adanya perbedaan kepentingan antara pemilik perusahaan dan manajer sehingga dapat menimbulkan berbagai masalah keagenan seperti pengeluaran yang berlebihan, keputusan investasi suboptimal dan asimetris informasi. Asimetris informasi terjadi ketika manajer memiliki lebih banyak informasi dibandingkan informasi yang dimiliki oleh pemilik perusahaan (Nugraha, 2015).

Perbedaan kepentingan antara principle dan agent dapat mempengaruhi berbagai hal yang berkaitan dengan kinerja perusahaan, salah satunya dalah kebijakan perusahaan mengenai pajak perusahaan. Sistem perpajakkan di Indonesia yang menggunakan self assessment system memberikan wewenang kepada perusahaan untuk menghitung dan melaporkan pajaknya sendiri. Penggunaan sistem ini dapat memberikan kesempatan bagi agent untuk memanipulasi pendapatan kena pajak menjadi lebih rendah sehingga beban pajak yang ditanggung perusahaan semakin kecil (Ardyansyah, 2014).

Terdapat beberapa cara untuk mengontrol tindakan agent terkait dengan

kegiatan manajemen pajak yang dilakukan, yaitu dengan mengevaluasi hasil laporan keuangan perusahaan dengan menggunakan rasio keuangan dibandingkan dengan tindakan agresivitas pajak yang mungkin dilakukan agent (Nugraha, 2015). Rasio yang digunakan adalah ukuran perusahaan, profitabilitas, leverage dan capital intensity yang dibandingkan ETR perusahaan yang didapat dari beban pajak dibanding laba sebelum pajak.

Sebuah perusahaan tergolong besar jika memiliki total asset yang besar pula. Total asset perusahaan dapat bertambah atau meningkat seiring dengan besarnya laba yang dihasilkan perusahaan (Nugraha, 2015). Total aset juga terus bertambah mengikuti semakin besarnya liabilitas dan ekuitas perusahaan karena mengharuskan adanya keseimbangan antara aset dengan liabilitas dan ekuitas. 
Semakin besar laba yang dihasilkan berarti semakin besar pula pendapatan kena pajak dan semakin besar pajak yang seharusnya dibayarkan namun bisa saja agent melakukan manipulasi sehingga harus dibandingkan dengan besarnya ETR perusahaan (Nugraha, 2015).

\subsection{Agresivitas Pajak}

Perusahaan menganggap pajak sebagai sebuah tambahan beban biaya yang dapat mengurangi keuntungan perusahaan. Oleh karena itu perusahaan diprediksi melakukan tindakan yang akan mengurangi beban pajak perusahaan. Menurut Frank dkk. (2009) dalam Gemilang (2017), tindakan yang dilakukan perusahaan untuk mengurangi pendapatan kena pajak melalui perencanaan pajak baik secara legal (tax avoidance) maupun illegal (tax evasion) disebut dengan agresivitas pajak perusahaan. Walaupun tidak semua tindakan perencanaan pajak melanggar hukum, akan tetapi semakin banyak celah yang digunakan maka perusahaan tersebut dianggap semakin agresif.

Pertimbangan untuk membayar pajak secara efisien yang mendorong perusahaan untuk menyusun perencanaan pajak (tax planning) melalui penghindaran pajak (tax avoidance) (Nugraha, 2015). Tax avoidance adalah suatu bentuk perencanaan pajak untuk meminimalkan beban pajak dengan memanfaatkan kelemahan ketentuan perpajakan sebagai hal yang positif untuk efisiensi pembayaran pajak. Sedangkan tax evasion merupakan sebuah perencanaan pajak yang melanggar ketentuan peraturan perundang-undangan perpajakan. Pada umumnya tingkat agresivitas pajak dipengaruhi oleh faktor manfaat dan risiko yang akan ditimbulkannya (Lanis dan Ricardson, 2012).

Agresivitas pajak merupakan isu yang kini cukup fenomenal di kalangan masyarakat. Agresivitas pajak terjadi hampir di semua perusahaan-perusahaan besar maupun kecil di seluruh dunia. Tindakan agresivitas pajak ini dilakukan dengan tujuan meminimalkan besarnya biaya pajak dari biaya pajak yang telah diperkirakan, atau dapat disimpulkan dengan usaha untuk mengurangi biaya pajak.

Menurut Hlaing (2012) dalam Nugraha (2015) agresivitas pajak didefinisikan sebagai kegiatan perencanaan pajak semua perusahaan yang terlibat dalam usaha mengurangi tingkat pajak yang efektif. Sementara Hanlon dan Heitzman (2010) dalam Nugraha (2015) mendefinisikan agresivitas pajak sebagai tingkat yang paling akhir dari spectrum serangkaian perilaku perencanaan pajak.

Manfaat agresifitas pajak perusahaan adalah penghematan pengeluaran atas pajak sehingga keuntungan yang diperoleh pemilik menjadi semakin besar untuk mendanai investasi perusahaan yang dapat meningkatkan keuntungan perusahaan dimasa yang akan datang (Suyanto dan Supramono, 2012) dalam Gemilang (2017). Sedangkan kerugian dari agresivitas pajak perusahaan adalah kemungkinan perusahaan mendapat sanksi dari kantor pajak berupa denda, serta turunnya harga saham perusahaan akibat pemegang saham lainnya mengetahui tindakan agresivitas pajak perusahaan. Bagi pemerintah, tindakan agresivitas pajak perusahaan ini akan mengurangi pendapatan Negara dalam sektor pajak (Suyanto, 2012).

Zuber (2007) dalam Yoehana (2013) menyatakan : 
"Between tax avoidance and tax evasion, there exist potential gray area of aggressiveness. This gray are exists because there are tax shelters beyond what is specifically allowed by the tax low and the tax law does not specifically address all possible tax transaction. A bright line does not exist between tax avoidance and tax evasion because neither term adequately describes all transaction. Therefore, aggressive transactions and decision-makin may potentially become either tax avoidance or tax evasion issues".

Dari kutipan diatas dapat disimpulkan bahwa tindakan pajak agresif atau keputusan agresivitas pajak secara potensial dapat menjadi masalah penghindaran pajak maupun masalah penggelapan pajak.

Agresivitas pajak dapat diukur dengan berbagai cara. Menurut Sari dan Martani (2010) agresivitas pajak dapat diukur dengan menggunakan effective tax rate, cash effective tax rate, book-tax difference Manzon-Plesko, book-tax difference desai-Dharmapala dan tax planning. Lanis dan Richardson (2012) menggunakan ETR untuk mengukur agresivitas pajak dengan alasan beberapa penelitian sebelumnya banyak menggunakan ETR untuk mengukur agresivitas pajak. Semakin rendah nilai ETR mengindikasikan adanya agresivitas pajak dalam perusahaan. ETR yang rendah menunjukkan beban pajak penghasilan yang lebih kecil dari pendapatan sebelum pajak.

Menurut Aunalal (2011) dalam Ardyansyah (2014) effetictive tax rate (ETR) dihitung atau dinilai berdasarkan pada informasi keuangan yang dihasilkan oleh perusahaan sehingga effective tax rate (ETR) merupakan bentuk perhitunggan tarif pajak pada perusahaan. Dari definisi tersebut effective tax rate (ETR) mempunyai tujuan untuk mengetahui jumlah persentase perubahan dalam membayar pajak yang sebenarnya terhadap laba komersial yang diperoleh.

\subsection{Likuiditas}

Likuiditas didefinisikan sebagai kepemilikan sumber dana yang memadai untuk memenuhi kebutuhan dan kewajiban yang akan jatuh tempo serta kemampuan untuk membeli dan menjual asset dengan cepat (Adisamartha dan Noviari, 2015). Perusahaan dengan rasio likuiditas yang tinggi menunjukkan kemampuan perusahaan untuk memenuhi kewajiban jangka pendeknya, yang menandakan perusahaan dalam kondisi keuangan yang sehat serta dengan mudah menjual aset yang dimilikinya jika diperlukan (Suyanto, 2012). Perusahaan yang memilki rasio likuiditas tinggi disebut perusahaan yang likuid. Masalah likuiditas merupakan salah satu masalah penting dalam suatu perusahaan yang relatif sulit dipecahkan (Suyanto, 2012).

Menurut Suyanto dan Supramono (2012) likuiditas sebuah perusahaan diprediksi dapat mempengaruhi tingkat agresivitas pajak perusahaan. Dimana jika sebuah perusahaan memiliki tingkat likuiditas yang tinggi, maka bisa digambarkkan bahwa arus kas perusahaan tersebut berjalan dengan baik. Dengan adanya perputaran kas yang baik maka perusahaan tidak enggan uuntuk membayar seluruh kewajibannya termasuk membayar pajak sesuai dengan aturan atau hukum yang berlaku. 


\subsection{Capital Intensity}

Capital intensity atau rasio intensitas modal adalah aktivitas investasi perusahaan yang dikaitkan dengan investasi aset tetap dan persediaan. Rasio intensitas modal dapat menunjukkan efisiensi penggunaan aktiva untuk menghasilkan penjualan (Yoehana, 2013). Capital intensity juga dapat didefinisikan dengan bagaimana perusahaan berkorban mengeluarkan dana untuk aktivitas operasi dan pendanaan aktiva guna memperoleh keuntungan perusahaan.

Capital intensity ratio dapat didefinisikan sebagai perusahaan menginvestasikan asetnya pada aset tetap dan persediaan. Dalam penelitian ini capital intensity diproksikan menggunakan rasio intensitas aset tetap. Intensitas aset tetap adalah seberapa besar proporsi aset tetap perusahaan dalam total aset yang dimiliki perusahaan (Ardyansyah, 2014). Rodriguez dan Arias (2012) dalam Ardyansah (2014) mengatakan bahwa aset tetap perusahaan memungkinkan perusahaan untuk mengurangi pajaknya akibat dari penyusutan yang muncul dari aset tetap setiap tahunnya. Hal ini karena beban penyusutan aset tetap ini secara langsung akan mengurangi laba perusahaan yang menjadi dasar perhitungan pajak perusahaan.

Mosebach dan Ellen (2007) dalam Yoehana (2013) menyatakan bahwa ada tiga intensitas untuk mengukur komposisi aktiva, yaitu intensitas persediaan, intensitas modal, dan intensitas penelitian dan pengembangan. Intensitas modal memiliki hubungan yang negative dengan ETR (Richardson dan Lanis, 2007). Menurut Hanum (2013) biaya depresiasi dapat dikurangkan dari penghasilan dalam menghitung pajak, maka semakin besar aset tetap yang dimiliki perusahaan mengakibatkan depresiasi yang besar juga sehingga mengakibatkan jumlah penghasilan kena pajak dan ETR nya berkurang.

\section{METODOLOGI PENELITIAN}

\subsection{Jenis Penelitian}

Pendekatan yang dilakukan dalam penelitian ini adalah pendekatan kuantitatif. Metode penelitian kuantitatif menurut Sugiyono (2015:7) adalah metode penelitian yang berlandaskan pada filsafat positivisme, pengumpulan data menggunakan instrumen penelitian, analisis data bersifat kuantitatif atau statistik, dengan tujuan untuk menguji hipotesis yang telah ditetapkan.

\subsection{Lokasi Penelitian}

Penelitian dilakukan di Bursa Efek Indonesia (BEI) pada periode 5 tahun mulai tahun 2012-2016. Pemilihan lokasi penelitian di Bursa Efek Indonesia (BEI) melalui situs resminya www.idx.co.id, didasarkan atas pertimbangan objektif sesuai dengan tujuan penelitian serta pertimbangan sebagai berikut :

1. Bursa Efek Indonesia (BEI) merupakan salah satu tempat transaksi perdagangan saham dari berbagai jenis perusahaan yang ada di Indonesia.

2. Bursa Efek Indonesia (BEI) memberikan informasi yang lengkap tentang datadata keuangan perusahaan dan perkembangan pergerakan harga saham. 


\subsection{Variabel dan Pengukuran}

\subsubsection{Variabel Dependen}

Variabel dependen adalah variabel yang dijelaskan atau dipengaruhi yang mnjadi akibat, karena adanya variabel bebas, Sugiyono (2012:39). Variabel dependen dalam penelitian ini adalah agresvitas pajak.

Variabel dependen yang digunakan dalam penelitian ini adalah agresivitas pajak. Agresivitas pajak adalah upaya perusahaan untuk meminimalkan beban pajak yang harus dibayar dengan cara yang legal, cara ilegal atau keduanya. Agresivitas pajak diukur dengan menggunakan proksi effective tax rate (ETR). ETR merupakan proksi yang banyak digunakan pada penelitian-penelitian sebelumnya. Lanis dan Richardson (2012) menyebutkan ada dua jenis ETR yang dapat digunakan sebagai proksi, atau disebut ETR1 dan ETR2, yang dihitung dengan cara:

$$
\begin{aligned}
& \text { ETR } 1=\frac{\text { Beban Pajak Penghasilan }}{\text { Laba Bersih Sebelum Pajak }} \\
& \text { ETR2 }=\frac{\text { Beban Pajak Penghasilan }}{\text { Arus Kas Operasi }}
\end{aligned}
$$

ETR1 menggambarkan presentase total beban pajak penghasilan yang dibayarkan perusahaan dari keseluruhan laba bersih sebelum pajak yang diperoleh perusahaan. Sedangkan ETR2 menggambarkan seberapa besar total beban pajak yang dibayarkan perusahaan dibandingkan dengan total arus kas dari aktivitas operasi perusahaan. Penelitian ini menggunakan ETR1 sebagai proksi mengukur agresivitas pajak. Lanis dan Richardson (2012) menyebutkan bahwa ETR yang rendah menunjukkan adanya agresivitas pajak.

\subsubsection{Variabel Independen}

Variabel independen adalah variabel yang menjadi sebab terjadinya atau yang mempengaruhi variabel dependen. Variabel independen dalam penelitian ini adalah likuiditas, dan capital intensity.

\section{1) Likuiditas}

Likuiditas menunjukkan kemampuan perusahaan dalam memenuhi kewajiban jangka pendek (Suyanto, 2012). Dalam penelitian ini likuiditas dihitung dengan menggunakan rasio lancar, alasannya karena rasio lancar merupakan rasio yang mengukur kemampuan perusahaan dalam jangka pendek dengan melihat aktiva lancar perusahaan terhadap utang lancarnya (utang dalam hal ini merupakan kewajiban perusahaan yang salah satunya adalah utang pajak).

$$
L I Q=\frac{\text { Aset Lancar }}{\text { Hutang Lancar }}
$$

\section{2) Capital Intensity}

Capital intensity menjelaskan seberapa besar perusahaan melakukan investasi pada aset. Berdasarkan penelitian Rodriguez dan Arias (2012) capital 
intensity diukur dengan menggunakan rasio antara aset tetap bersih dibagi total aset, atau dapat dirumuskan sebagai berikut:

$$
\text { CAPIN }=\frac{\text { Aset Tetap Bersih }}{\text { Total Aset }}
$$

\subsection{Populasi dan Sampel}

\subsubsection{Populasi}

Menurut Sugiyono (2015:80) populasi adalah "wilayah generalisasi yang terdiri atas objek dan subjek yang mempunyai kualitas dan karakteristik tertentu yang ditetapkan oleh peneliti untuk dipelajari dan kemudian ditarik kesimpulannya".

Alasan memilih perusahaan manufaktur adalah karena perusahaan yang terdapat didalam industri manufaktur adalah yang jumlahnya paling banyak dibandingkan dengan industri lain, dan diharapkan mampu menggambarkan keadaan di Indonesia. Dan juga untuk menghindari bias efek industri.

Metode yang digunakan dalam pengambilan sampel adalah metode purposive sampling. Purposive sampling adalah metode pengambilan sampel yang disesuaikan dengan kriteria tertentu agar sampel yang terpilih lebih representatif.

\subsubsection{Sampel}

Menurut Sugiyono (2015:81) sampel adalah sebagian dari jumlah dan karakteristik yang dimiliki oleh populasi tersebut. sampel dalam penelitian ini terdapat 12 sampel perusahaan manufaktur yang terdaftar di Bursa Efek Indonesia tahun 2012-2016.

Berikut adalah kriteria-kriteria pengambilan sampel menggunakan metode purposive sampling dalam penelitian ini:

1) Perusahaan tidak memiliki laba sebelum pajak yang rugi atau negatif selama periode 2012-2016, karena akan mengakibatkan ETR yang negatif.

2) Perusahaan yang menggunakan satuan nilai rupiah dalam laporan keuangannyaselama tahun penelitian.

3) Perusahaan yang tidak mengalami kerugian atau memperoleh laba selama tahun penelitian.

4) Perusahaan yang mempublikasikan laporan tahunan (annual report) dan laporan keuangan pada tahun 2012-2016 secara lengkap.

5) Perusahaan yang memiliki nilai ETR antara 0-1, karena semakin rendah nilai ETR (mendekati 0) maka perusahaan dianggap semakin tinggi tingkat penghindaran pajaknya, sementara semakin tinggi nilai ETR (mendekati 1) maka perusahaan dianggap semakin rendah tingkat penghindaran pajaknya.

\subsection{Teknik Analisis}

Teknik analisis data adalah suatu teknis yang digunakan unuk mengolah hasil penelitian guna memperoleh sutu kesimpulan. Dlam penelitian ini analisis yang digunakan yaitu analisis kuantitatif dengan bantuan SPSS 22.0 dan Microsoft Excel. 
Statistik deskriptif memberikan gambaran atau deskripsi suatu data yang dilihat dari nilai rata - rata (mean), standar deviasi, minimum, maximum (Gozali, 2016:19). Analisis statistic deskriptif bertujuan untuk memberikan gambaran mengenai distribusi dan perilakuk data sampel penelitian.

\section{ANALISIS DATA}

\subsection{Deskripsi Sample}

Populasi dalam penelitian ini adalah perusahaan sektor manufaktur yang terdaftar di Bursa Efek Indonesia (BEI) periode 2012 sampai 2016. Adapun penelitian ini dilakukan untuk mengetahui seberapa besar pengaruh Liuiditas dan capital intensity terhadap agresivitas pajak. Berdasarkan kriteria yang telah ditetapkan pada bab sebelumnya, maka peneliti memakai sampel sebanyak 44 perusahaan manufaktur sektor industri dasar dan kimia yang telah terdaftar di Bursa Efek Indonesia periode 2012 samapi dengan 2016.

Adapun proses seleksi sampel berdasarkan kreteria yang telah ditetapkan dapat dilihat pada tabel 4.1 sebagai berikut:

Table 4.1

Proses Seleksi Sample purposive sampling

\begin{tabular}{|c|l|c|}
\hline No & Kriteria & Jumlah \\
\hline 1 & $\begin{array}{l}\text { Perusahaan Manufaktur Sektor Industri Dasar Dan } \\
\text { Kimia yang terdaftar di Bursa Efek Indonesia (BEI) } \\
\text { selama periode penelitian (2012-2016) }\end{array}$ & 44 \\
\hline 2 & $\begin{array}{l}\text { Perusahaan yang tidak mempublikasikan laporan } \\
\text { keuangan periode tahun 2012-2016 }\end{array}$ & 16 \\
\hline 3 & $\begin{array}{l}\text { Perusahaan yang menggunakan mata uang asing pada } \\
\text { periode 2012-2016 }\end{array}$ & 6 \\
\hline 4 & $\begin{array}{l}\text { Perusahaan yang mengalami kerugian sebelum pajak } \\
\text { tahun berjalan selama tahun penelitian }\end{array}$ & 14 \\
\hline 6 & Jumlah sampel penelitian terpilih & 5 \\
\hline 7 & Jumlah pengamatan (tahun) & 70 \\
\hline 8 & $\begin{array}{l}\text { Jumlah sampel total selama periode penelitian (14 x } \\
\text { 5) }\end{array}$ & \\
\hline
\end{tabular}

\subsection{Analisis Statistik Deskriptif}

Statistik deskriptif pada masing-masing variabel yaitu likuiditas (LIQ), Capital Intensity (capint), dan Agresivitas Pajak yang akan ditampilkan pada tabel 
4.2 dibawah ini akan memberikan gambaran mengenai mean, standard deviation, maximum dan minimum dari setiap variabel yang digunakan dalam penelitian ini.

Tabel 4.2. Hasil Uji Statistik Deskriptif Descriptive Statistics

\begin{tabular}{|l|r|r|r|r|r|}
\hline & $\mathrm{N}$ & $\begin{array}{r}\text { Minimu } \\
\mathrm{m}\end{array}$ & $\begin{array}{c}\text { Maximu } \\
\mathrm{m}\end{array}$ & \multicolumn{1}{c|}{ Mean } & $\begin{array}{c}\text { Std. } \\
\text { Deviation }\end{array}$ \\
\hline Likuiditas & 70 &, 07 & 1,00 &, 4744 &, 29342 \\
Capital intensity & 70 &, 04 &, 70 &, 3437 &, 17617 \\
Agresivitas Pajak & 70 &, 03 &, 56 &, 2482 &, 11022 \\
Valid N (listwise) & 70 & & & & \\
\hline
\end{tabular}

Output SPSS 22.0 data sekunder yang diolah 2017

Pada tabel 4.2 Statistik Deskriptif diperoleh sebanyak 70 data observasi yang berasal dari perkalian periode penelitian (5 tahun, yaitu dari tahun 2012 sampai dengan tahun 2016) dengan jumlah sampel sebanyak 14 perusahaan. Tabel diatas menggambarkan deskripsi variable-variabel penelitian secara statistic. Minimum adalah nilai terkecil dari pengamatan, maximum adalah nilai terbesar dari pengamatan, mean adalah hasil penjumlahan nilai seluruh data dibagi dengan banyaknya data, dan standard deviasi adalah akar dari jumlah kuadrat selisih nilai data dengan rata-rata dibagi dengan banyaknya data.

Tabel 4.2 menunjukkan deskriptif variable penelitian dengan jumlah data setiap variable sebanyak 60 adalah sebagai berikut :

a. Likuiditas dalam penelitian ini memiliki nilai nilai minimum 0,07 , nilai maximum 0,35, dan rata-rata 0,4744 dengan standar deviasi 0,29342.

b. Capital Intensity dalam penelitian ini memiliki nilai minimum 0,04 , nilai maximum 0,70, dan nilai rata-rata 0,3437 dengan standar deviasi 0,17617.

c. Agresivitas Pajak dalam penelitian ini memiliki nilai minimum 0,03, nilai maximum 0,56, dan rata-rata 0,2482 dengan standar deviasi 0,11022 .

\subsection{Hasil Penelitian}

\subsubsection{Uji Asumsi Klasik}

Pengujian asumsi klasik bertujuan untuk mengetahui dan menguji kelayakan atas model regresi yang digunakan atas model penelitian ini. Berikut ini uji asumsi klasik yang dilakukan dalam penelitian ini.

\section{1) Uji Normalitas}

Model regresi yang baik adalah distribusi data normal atau mendekati normal. Dalam uji normalitas ini, keseluruhannya dideteksi dengan melihat penyebaran data (titik) pada sumbu diagonal dari grafik atau dengan melihat histogram dari residualnya.

Dengan menggunakan program SPSS versi 22, Adapun uji normalitas dapat dilihat pada gambar 4.1 berikut ini: 


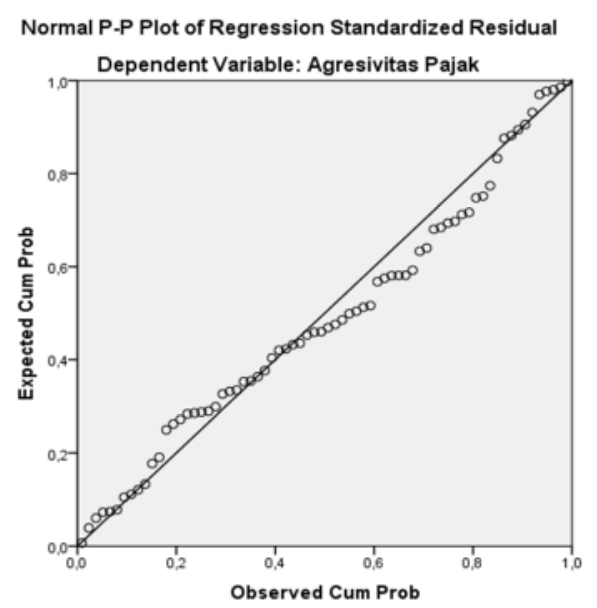

Sumber: IBM SPSS 22 Data diolah

Gambar 4.1

Grafik Normal P-P Plot

Berdasarkan gambar 4.1 grafik Normal P-P Plot di atas, terlihat bahwa titik-titik menyebar di sekitar garis diagonal, serta penyebaranya mengikuti arah garis diagonal, maka regresi memenuhi asumsi normalitas.

Uji statistik lain yang dapat diguakan dalam persyaratan normalitas yaitu menggunakan uji statistik Non-parametic test Kolmogorov-Smirno (K-S) yaitu sebagai berikut:

Tabel 4.3

One-Sample Kolmogorov-Smirnov Test

\begin{tabular}{|ll|r|}
\hline & & $\begin{array}{c}\text { Unstandardized } \\
\text { Residual }\end{array}$ \\
\hline $\mathrm{N}$ & & 70 \\
Normal Parameters & Mean &, 0000000 \\
& Std. &, 09800710 \\
Most Extreme & Deviation &, 092 \\
Differences & Absolute &, 092 \\
& Positive &,- 075 \\
Test Statistic & Negative &, 092 \\
Asymp. Sig. (2-tailed) & &, $200^{\mathrm{c}, \mathrm{d}}$ \\
\hline
\end{tabular}

a. Test distribution is Normal.

b. Calculated from data.

c. Lilliefors Significance Correction.

$\mathrm{d}$. This is a lower bound of the true significance.

Sumber: IBM SPSS 22 Data diolah

Dari table 4.3 diatas dapat dilihat bahwa test statistic Kolmogorov-Smirno adalah 0.92 dan signifikan pada 0.200 , dalam penelitian ini menggunakan tingkat kepercayaan signifikansi sebesar 0,05 $(\alpha=5 \%)$, maka dapat dikatakan bahwa 
model regresi yang di uji memenuhi asumsi normal. Dan dari hasil diatas dapat dilihat Asymp.Sig sebesar 0.200 , maka H0 dianggap normal karena residual signifikan lebih besar dari $0.05(0.200>0.05)$.

\section{2) Uji Multikolinieritas}

Uji multikolinieritas digunakan untuk mengetahui apakah model regresi mempunyai korelasi antara variabel bebas. Serta mendeteksi ada tidaknya multikolinieritas di dalam regresi, dapat dilihat dari nilai tolerance dan nilai variance inflation factor (VIF). Nilai yang menunjukan adanya multikolinieritas adalah nilai tolerance $\leq 0,10$ atau sama dengan nilai $\mathrm{VIF} \geq 10$. Sebaliknya apabila nilai tolerance $\geq 0,10$ atau sama dengan nilai $\mathrm{VIF} \leq 10$, maka tidak terjadi multikolinieritas.

Tabel 4.4

\section{Uji Multikolinieritas}

Coefficients $^{\mathrm{a}}$

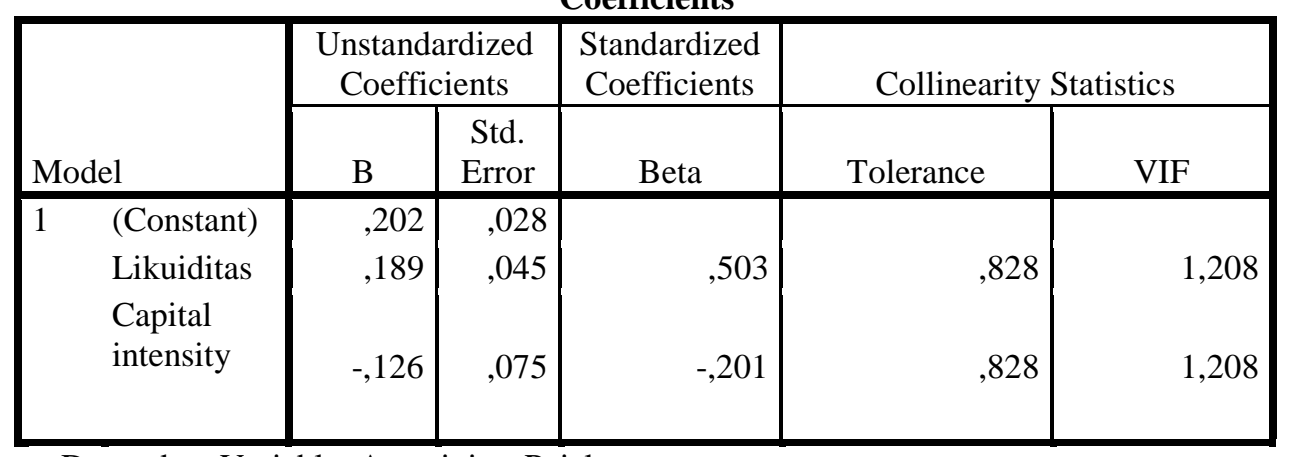

a. Dependent Variable: Agresivitas Pajak

Sumber: IBM SPSS 22 Data diolah

Berdasarkan tabel 4.4 diatas, dapat dilihat bahwa likuiditas memiliki nilai tolerance $\geq 0.10$ yaitu sebesar 0.828 dan memiliki nilai $\mathrm{VIF} \leq 10$ yaitu sebesar 1,208 . Dan untuk capital intensity memiliki nilai tolerance $\geq 0.10$ yaitu sebesar 0.828 dan memiliki nilai VIF $\leq 10$ yaitu sebesar 1.208 .

Maka dapat dilihat bahwa data yang ada tidak terjadi multikolonieritas antara masing-masing variable independent yaitu dengan melihat nilai VIF dan tolerance. Nilai VIF yang diperbolehkan hanya mencapai $\geq 10$ dan nilai tolerance $\leq$ dari 0,10 . Maka pada tabel 4.4 data diatas dapat dipastikan tidak terjadi gejala multikolonieritas.

\section{3) Uji Heteroskedastisitas}

Model regresi yang baik adalah uji yang tidak terjadi heteroskesdasitas. Uji ini dilakukan untuk menguji apakah dalam model regresi terjadi ketidaksamaan varians dari residual satu pengamatan ke pengamatan yang lain untuk melihat penyebaran data. 


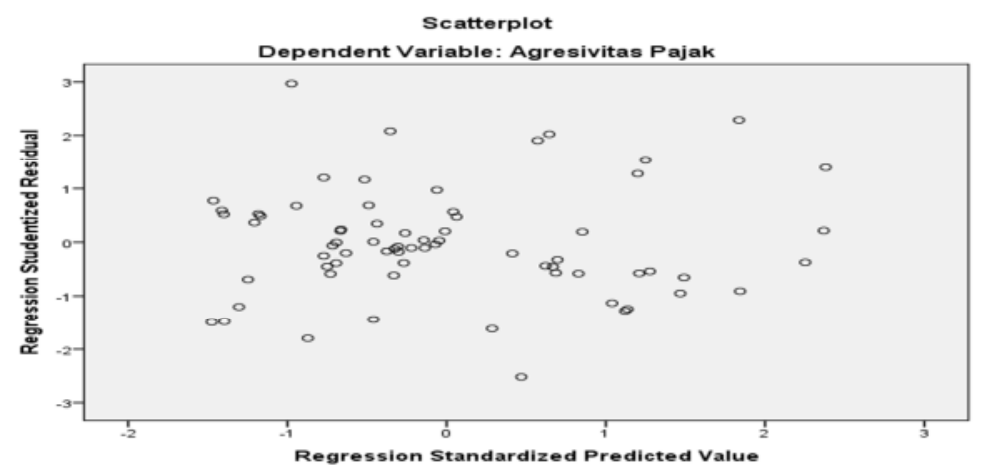

Sumber: IBM SPSS 22 Data diolah

Gambar 4.2

Hasil Uji Heteroskedastisitas

Dari hasil gambar 4.2 terlihat bahwa tidak terdapat pola yang jelas, serta titik-titik menyebar diatas dan dibawah angka 0 pada sumbu $\mathrm{Y}$, hal ini dapat disimpulkan bahwa tidak terjadi heterokesdastisitas pada model regresi, sehingga model regresi ini layak digunakan untuk melakukan penelitian.

\section{4) Uji Autokorelasi}

Model regresi yang baik adalah model yang bebas dari autokorelasi.

Tabel 4.5. Hasil Uji Autokorelasi dengan DW Model Summary ${ }^{\text {b }}$

\begin{tabular}{|l|c|r|r|r|r|}
\hline Model & R & R Square & $\begin{array}{c}\text { Adjusted R } \\
\text { Square }\end{array}$ & $\begin{array}{c}\text { Std. Error of } \\
\text { the Estimate }\end{array}$ & $\begin{array}{c}\text { Durbin- } \\
\text { Watson }\end{array}$ \\
\hline 1 &, $458^{\mathrm{a}}$ &, 209 &, 186 &, 09946 & 1,073 \\
\hline
\end{tabular}

a. Predictors: (Constant), Capital intensity, Likuiditas

b. Dependent Variable: Agresivitas Pajak

Sumber: IBM SPSS 22 Data diolah

Berdasarkan uji autokorelasi pada tabel 4.5 diatas dengan menggunakan SPSS 22, telah didapat nilai Durbin Watson (DW) sebesar 1.073. Signifikasi 5\% jumlah sampel $70(\mathrm{n})$ dan jumlah variabel independen $2(\mathrm{k}=2)$, diperoleh batas atas (du) sebesar 1.6715 dan batas bawah (dl) 1.5542. Nilai DW 1.073 lebih kecil dari batas atas (du) 1.6715 dan batas bawah (dl) 1.5542, ini berarti nilai tersebut berada dalam kritria $0<\mathrm{d}<\mathrm{dl}$ yaitu $(0<1.073<1.5542$ ). Maka H0 ditolak yang menyatakan bahwa dalam penelitian ini tidak ada autokorelasi positif,

Dari hasil uji DW di atas, dapat disimpulan bahwa tidak ada autokorelasi positif. Untuk lebih meyakinkan, maka peneliti melakukan uji ke dua, yaitu dengan uji Run Test. Run Test digunakan untuk melihat apakah data residual terjadi secara random atau tidak. Jika nilai Asyim. Sig. (2-tailed) < 0,05 maka H0 ditolak, data residual tidak random atau terjadi autokorelasi antar nilai residual. Namun jika Asyim. Sig. (2-tailed) > 0,05 maka H0 diterima, data residual random atau tidak terjadi autokorelasi anatar residual 
Berikut ini adalah tabel 4.6 dan merupakan hasil uji Run Test dengan menggunakan aplikasi SPSS 22 yaitu sebagai berikut:

Tabel 4.6

Uji Run Test

\begin{tabular}{|l|r|}
\hline & $\begin{array}{r}\text { Unstandardiz } \\
\text { ed Residual }\end{array}$ \\
\hline Test Value $^{\mathrm{a}}$ &,- 00889 \\
Cases < Test Value & 35 \\
Cases > = Test & 35 \\
Value & 70 \\
Total Cases & 29 \\
Number of Runs & $-1,686$ \\
Z &, 092 \\
Asymp. Sig. (2- & \\
tailed) &
\end{tabular}

a. Median

Dari pengujian gejala autokorelasi tabel 4.6 di atas, maka dapat ditarik kesimpulan bahwa model penelitian yang digunakan tidak mengandung gejala autokorelasi. Hal ini dapat dilihat dari nilai Asyim. Sig. (2-tailed) sebesar 0,092 > 0,05 .

\subsection{Uji Hipotesis}

\subsubsection{Uji Regresi Linier Berganda}

Berdasarkan uji statistik dengan menggunakan software program SPSS, diperoleh hasil regresi linier berganda sebagai berikut :

\section{Tabel 4.7}

\section{Hasil Uji Regresi Linier Berganda}

\begin{tabular}{|l|r|r|}
\hline \multirow{2}{*}{ Model } & \multicolumn{2}{|c|}{ Unstandardized Coefficients } \\
\cline { 2 - 3 } (Constant) & B & \multicolumn{1}{c|}{ Std. Error } \\
Likuiditas &, 202 &, 028 \\
Capital intensity &, 189 &, 045 \\
&,- 126 &, 075 \\
\hline
\end{tabular}

a. Dependent Variable: Agresivitas Pajak

Sumber: Output SPSS 22.0, data sekunder yang diolah

Berdasarkan hasil coefficients di tabel 4.7 atas, dapat dikembangkan dengan menggunakan model persamaan regresi linier berganda yaitu sebagai berikut:

TAGit $=\alpha 0+\beta 1 \mathrm{LIQ}+\beta 3 \mathrm{CAPIN}+\mathrm{e}$

maka persamaan regresi bergandanya adalah sebagai berikut:

agresivitas pajak $(\mathrm{Y})=0,202+0,189(\mathrm{LIQ})-0,126(\mathrm{CAPIN})+e$ 
1) Nilai konstanta pada persamaan regresi sebesar 0,202 menunjukkan bahwa jika variabel independen bernilai nol, maka variabel agresivitas pajak memiliki nilai sebesar 0,202 satuan.

2) Koefisien regresi variabel likuiditas (X1) sebesar 0,189 menunjukkan bahwa jika variabel likuiditas meningkat satu satuan dengan mengansumsikan variabel lainnya tetap, maka variabel agresivitas pajak akan mengalami kenaikan sebesar 0,189.

3) Koefisien regresi variabel Capital Intensity sebesar - 0,126 menunjukkan bahwa jika variabel Capital Intensity meningkat satu satuan dengan mengansumsikan variabel lainnya tetap, maka variabel agresivitas pajak akan mengalami penurunan sebesar - 0,126.

\subsubsection{Koefisien Determinasi $\left(R^{2}\right)$}

Dalam uji ini, variabel yang digunakan lebih dari satu, yaitu tiga variabel independen. Hal ini akan semakin menentukan seberapa besar persentase yang dihasilkan dari ketiga variabel independen tersebut terhadap variabel dependen yang ada. Karena pada dasarnya variabel independen yang ada tersebut adalah untuk menjelaskan fluktuasi variabel dependen dalam penelitian.

Berikut ini adalah tabel 4.8 dan merupakan hasil perhitungan koefisien determinasi dengan menggunakan applikasi SPSS 22 yaitu sebagai berikut:

Tabel 4.8. Hasil Uji Koefisien Determinasi $\left(\operatorname{Adj} \boldsymbol{R}^{2}\right)$ Model Summary ${ }^{b}$

\begin{tabular}{|l|l|r|r|r|}
\hline Model & R & R Square & $\begin{array}{c}\text { Adjusted R } \\
\text { Square }\end{array}$ & $\begin{array}{c}\text { Std. Error of the } \\
\text { Estimate }\end{array}$ \\
\hline 1 &, $458^{\mathrm{a}}$ &, 209 &, 186 &, 09946 \\
\hline
\end{tabular}

a. Predictors: (Constant), Capital intensity, Likuiditas

b. Dependent Variable: Agresivitas Pajak

Sumber: Output SPSS 22.0, data sekunder yang diolah

Dari tabel 4.8 di atas diketahui bahwa nilai Adjusted $R$ Square sebesar 0,209 atau 20,9\%, hal tersebut menunjukan bahwa agresivitas berhubungan dengan likuiditas, dan Capital Intensity adalah sebesar 20,9\%, sedangkan sisanya 79,1 \% dijelaskan oleh variabel lain seperti Leverage (Suyanto : 2012), (Fikriyah : 2013), (Fransisca : 2013), (Ardyansah : 2014), (Nugraha : 2015), (Adisamartha : 2015), (Fadli : 2016), CSR (Nugraha : 2015), Proftabilitas (Fikriyah : 2013), (Ardyansah, 2014), (Nugraha : 2015), Ukuran perusahaan (Ardyansah : 2014), (Nugraha : 2015), komisaris independen (Suyanto : 2012), (Ardyansah : 2014), (Fadli : 2016), Intensitas persediaan (Adisamartha : 2015), Manajemen laba (Suyanto :2012), 9 (Fadli : 2016), Karakteristik Kepemilikan (Fikriyah : 2013), kepemilikan institusional (Fadli : 2016). 


\subsubsection{Uji Parsial (Uji Statistik t)}

Dalam penelitian ini menggunakan tingkat signifikansi sebesar $0,05(\alpha=$ $5 \%)$. dengan derajat $\mathrm{df}=(\mathrm{n}-\mathrm{k}-1)$ dimana $\mathrm{n}$ adalah jumlah obsrvasi dan $\mathrm{k}$ adalah jumlah variabel. Dimana pada tingkat 95\% dengan $\alpha=5 \%$ dan $\mathrm{df}=60-3-1=56$ Kriteria penerimaan dan penolakan hipotesis:

1. H0 diterima, Ha ditolak apabila: $\mathrm{t}-\mathrm{htg}<\mathrm{t}$-tabel atau nilai Sig. $>0.05$

2. H0 ditolak, Ha diterima apabila: t-htg $>$ t-tabel atau nilai Sig. $<0.05$

Hasil uji $\mathrm{t}$ dalam penelitian ini menggunakan applikasi SPSS 22 dan ditunjukkan dalam tabel dibawah ini :

Tabel 4.9. Hasil Uji Parsial (Uji Statistik t)

Coefficients $^{\mathrm{a}}$

\begin{tabular}{|l|r|r|r|r|r|}
\hline \multirow{2}{*}{ Model } & \multicolumn{2}{|c|}{$\begin{array}{c}\text { Unstandardized } \\
\text { Coefficients }\end{array}$} & $\begin{array}{c}\text { Standardized } \\
\text { Coefficients }\end{array}$ & \multirow{2}{*}{} & \multirow{2}{*}{ Sig. } \\
\cline { 2 - 4 } & \multicolumn{1}{c|}{ B } & Std. Error & \multicolumn{1}{c|}{ Beta } & \multicolumn{1}{c|}{ t } & ,000 \\
(Constant) &, 202 &, 028 & & 7,137 &, 000 \\
Likuiditas &, 189 &, 045 &, 503 & 4,211 &, 097 \\
Capital &,- 126 &, 075 &,- 201 & $-1,684$ &, \\
intensity & -126 & & & \\
\hline
\end{tabular}

a. Dependent Variable: Agresivitas Pajak

Sumber: IBM SPSS 22 Data diolah

\section{1) Uji Hipotesis pertama (H1)}

Berdasarkan hasil uji $\mathrm{t}$ pada variabel likuiditas, diperoleh $\mathrm{t}$ hitung sebesar 7,137 dengan tingkat signifikan sebesar 0,000. nilai t hitung > t tabel $(7,137>1,66691)$, karena tingkat signifikan yang dimiliki variabel likuiditas $<0,05(0,000<0,05)$ sehingga dapat disimpulkan bahwa H0 ditolak. Jadi dapat disimpulkan bahwa hipotesis pertama (H1) likuiditas berpengaruh terhadap agresivitas pajak.

\section{2) Uji Hipotesis Kedua (H2)}

Berdasarkan hasil uji t pada variabel Capital Intencity, diperoleh t hitung sebesar -1,684 dengan tingkat signifikan sebesar 0,97. Karena tingkat signifikan yang dimiliki variabel Capital intensity $>0,05(0,97>0,05)$ dan nilai $\mathrm{t}$ hitung $<\mathrm{t}$ tabel $(-1,684<1,66691)$ sehinggan dapat disimpulkan bahwa H0 diterima. Jadi dapat disimpulkan Capital Intensity tidak berpengaruh terhadap agresivitas pajak.

\subsubsection{Uji Statisitik F}

Dalam uji F, dipergunakan hipotesis sebagai berikut:

1. H0 diterima, Ha ditolak apabila $\mathrm{F}$ hitung $<\mathrm{F}$ tabel atau nilai Sig. $>0.05$

2. H0 ditolak, Ha diterima apabila F hitung $>$ F tabel atau nilai Sig. $<0.05$ Hasilnya dapat dilihat pada table 4.10 sebagai berikut: 
Tabel 4.10. Uji Signifikansi Simultan (Uji F) ANOVA $^{\mathrm{a}}$

\begin{tabular}{|c|c|c|c|c|c|}
\hline Model & $\begin{array}{l}\text { Sum of } \\
\text { Squares }\end{array}$ & Df & Mean Square & $\mathrm{F}$ & Sig. \\
\hline 1 Regression &, 175 & 2 & ,088 & 8,870 &, $000^{\mathrm{b}}$ \\
\hline Residual & ,663 & 67 & ,010 & & \\
\hline Total & ,838 & 69 & & & \\
\hline
\end{tabular}

a. Dependent Variable: Agresivitas Pajak

b. Predictors: (Constant), Capital intensity, Likuiditas

Sumber: IBM SPSS 22 Data diolah

\section{3) Uji Hipotesis Ketiga (H3)}

Dari uji ANOVA (Analysis Of Varians) atau Uji F, menunjukan bahwa nilai $\mathrm{F}$ hitung sebesar 8,870 dengan nilai signifikansi sebesar 0,000 . berdasarkan $\mathrm{F}$ tabel yang ada, jumlah sampel $(\mathrm{n})=70$, jumlah variabel $(\mathrm{k}=2)$, taraf signifikansi=0,05 atau 5\% maka didapatkan nilai $\mathrm{F}$ tabel sebesar 3,13.

Karena tingkat signifikan $<0,05(0,006<0,05)$ dan nilai $\mathrm{F}$ hitung $>\mathrm{F}$ tabel $(8,870>3,13)$ sehingga dapat disimpulkan bahwa H0 ditolak. Jadi dapat ditarik kesimpulan bahwa hipotesis ketiga (H3) likuiditas dan Capital Intensity berpengaruh terhadap agresivitas pajak.

\section{KESIMPULAN DAN SARAN}

\subsection{Kesimpulan}

Penelitian ini bertujuan untuk membuktikan secara empiris pengaruh likuiditas dan Capital Intensity terhadap agresivitas pajak. Objek penelitian yang menjadi sampel penelitian ini adalah 14 perusahaan manufaktur pada sektor industri dasar dan kimia selama tahun 2012-2016. Berdasarkan hasil pengujian yang telah dijelaskan sebelumnya, maka diperoleh beberapa kesimpulan sebagai berikut :

1. Likuiditas menunjukan berpengaruh terhadap agresivitas pajak.

2. Capital Intensity menunjukan tidak berpengaruh terhadap agresivitas pajak.

3. Likuiditas dan apital Intensity secara simultan menunjukan berpengaruh terhadap agresivias pajak.

\subsection{Saran}

Berdasarkan hasil penelitian serta hal-hal yang terkait dengan kesimpulan yang telah diperoleh, maka saran dari penulis untuk penelitian selanjutnya adalah sebagai berikut :

1. Bagi peneliti, sebaiknya menganalisa berbagai sektor perusahaan selain manufaktur pada sub sektor industr dasar dan kimia, sehinggan menghasilkan hasil penelitian yang lebih variasi lagi.

2. Penelitian selajutnya, peneliti dapat menambahkan variabel-variabel lain yang ada diluar model penelitian untuk mendapatkan hasil yang lebih varian dan lebih baik lagi. 


\section{DAFTAR PUSTAKA}

Ardyansah (2014). Pengaruh Size, Leverage, Profitability, Capital Intensity Ratio Dan Komisaris Independen Terhadap Effective Tax Rate (Etr). (Studi Empiris pada Perusahaan Manufaktur yang Terdaftar Di BEI Selama Periode 2010-2012). The 1st Accounting And Busines, Faculty Of Economic University Of Diponegoro,Semarang.

Fikriyah (2013). Analisis pengaruh likuiditas, leverage, profitabilitas, dan karakteristik kepemilikan terhadap agresivitas pajak perusahaan (Studi pada perusahaan sektor pertambangan yang terdaftar di bei tahun 20102012). Malang.

Gemilang (2017). Pengaruh Likuiditas, Leverage, Profitabilitas, Ukuran Perusahaan Dan Capital Intensity Terhadap Agresivitas Pajak Perusahaan (Studi Empiris Pada Perusahaan Property dan Real Estate Yang Terdaftar di BEI Pada Tahun 2013-2015) The 1st Accounting And Busines, Faculty Of Economic and busines IslamicUniversity Of Diponegoro,Surakarta.

Gozali, Imam, (2013). Aplikasi Analisis Multivariate dengan program IMB SPSS 21 edisi tujuh semarang, universitas diponegoro

Imam Fadli (2016). Pengaruh Likuiditas, Leverage, Komisaris Independen, Manajemen Laba,Dan Kepemilikan Institusional Terhadap Agresivitas Pajak Perusahaan (Studi pada perusahaan manufaktur yang terdaftar di Bursa Efek Indonesia periode 2011-2013). JOM Fekon, Vol.3 No.1 (Februari) 2016, Faculty of Economics Universitas Riau, Pekanbaru, Indonesia

Kuncoro, Mudrajad (2009). Metode Riset Untuk Bisnis Dan Ekonomi : Bagaimana Meneliti Dan Menulis Tesis. Edisi Ke 3, Erlangga, Jakarta.

Lanis, R. and G. Richardson. (2007). Determinant Of The Variability In Corporate Effective Tax Rates And Tax Reform : evidence From Australia . Journal Accounting Of Public Policy, Australia pp. 689- 704.

Lanis, R. and G. Richardson. (2012). Corporate Social Responsibility and Tax Aggressiveness: An Empirical Analysis. Journal Accounting Of Public Policy, Australia pp.86-108.

Peraturan Pemerintah No.46 Tahun (2013). Peredaran bruto dari usaha dalam satu tahun pajak

Nugraha, (2015). Pengaruh Corporate Social Responsibility, Ukuran Perusahaan, Profitabilitas, Leverage Dan Capital Intensity Terhadap Agresivitas Pajak. (Studi Empiris pada Perusahaan Non Keuangan yang Terdaftar di Bursa Efek Indonesia 2012-2013), DIPONEGORO JOURNAL OF ACCOUNTING Volume 4, Nomor 4, Tahun 2015, Halaman 1-14 ISSN (Online): 2337-3806

Pradnyadari (2015). Pengaruh Pengungkapan Corporate Social Responsibility Terhadap Agresivitas Pajak. DIPONEGORO JOURNAL OF ACCOUNTING Volume 4, Nomor 2, Tahun 2015, Halaman 1-9 ISSN (Online): 2337-3806

Rodriguez dan Arias (2012). Do Bussines Characteristics Determine An Effective Tax Rate, The Chinese Economy, 60 - 83 
Sari, D.K., dan Martani, D. (2010). Ownership characteristics, corporate governance and tax aggressiveness. The 3rd International Accounting Conference \&The 2nd Doctoral Colloquium. Bali.

Sugiyono. (2015). Metode Penelitian Kuantitatif, kualitatif dan R\&D, Alfabeta. Bandung

Suyanto, K.D., dan Suparmono. (2012). Likuiditas, leverage, komisaris independen,dan manajemen laba terhadap afresivitas pajak perusahaan. Jurnal Keuangan dan Perbankan. Vol 16, No. 2, hlm 167-177.

Undang-Undang Dasar 1945 Amandemen III ,pemungutan pajak diatur dengan Undang-Undang

Undang-Undang No. 28 Tahun 2007, Ketentuan Umum dan Tata Cara Perpajakan Undang-Undang no. 36 tahun 2008, pajak penghasilan (PPh)

Undang-Undang No. 36 Tahun 2009, penurunan tarif PPh badan

Waluyo, 2011, Perpajakan Indonesia, Edisi Kesepuluh, Jakarta: Salemba Empat. www.cnnindonesia.com Realisasi Penerimaan Negara pada Kuartal 12016 , diakses pada 25 Februri 2017

Yoehana (2013). Analisis Pengaruh Corporate Socialresponsibility Terhadap Agresivitaspajak (Studi Empiris pada Perusahaan Manufaktur yang Terdaftar di Bursa Efek Indonesia Tahun 2010-2011. The 1st Accounting And Busines, Faculty Of Economic University Of Diponegoro,Semarang. 